It is possible that Professor Nutting excluded from his consideration all museums which were wholly or partly supported by public funds, but the inference drawn from the paragraph quoted above is that there are no museums in the central states which are following along the lines indicated in his paper. There are at least two museums which should be classed as provincial museums which are now doing (and have been for some time past) the work outlined in Professor Nutting's paper, viz., the Public Museum of Milwaukee and the Chicago Academy of Sciences.

Both of the institutions mentioned are making extensive local collections, the exhibits are arranged and labeled with special reference to the education of the public, loans of material are made to the schools and large study collections are being acquired for research work. Free public lectures are maintained in the latter institution.

This statement is made with no desire to criticize Professor Nutting's very excellent paper, but simply to rectify a manifestly misleading statement, the inaccuracy of which doubtless escaped the notice of the author.

Frank C. Baker

\section{MILK PROTEINS}

To the Editor of Science: The October number of the Journal of Biological Chemistry contained an article entitled "Milk Proteins," by Geo. A. Olson, and written as a "Contribution from the Agricultural Chemical Laboratory of the University of Wisconsin." It is generally assumed that when articles appear under the above caption they have received the sanction of those in charge of the laboratory from which they emanate. I desire to state that in this case Mr. Olson is entirely responsible for the material of his article and that those in charge of the laboratory assume no responsibility whatever for the deductions therein stated. I trust you will find a place in an early issue of ScIEnce for this note.

UNIVERSTTY OF WISCONSIN,

E. B. $\mathrm{H}_{\mathrm{ART}}$

November 2, 1908

\section{QUOTATIONS}

THE RETIREMENT OF PRESIDENT ELIOT

THE announcement that President Eliot is to retire next March will come as a shock to thousands of persons who have never even seen University Hall. The country has come to look upon him as a great natural force, like the Gulf Stream, unwearied by the flight of time, unworn by incessant activity. Yet at the age of seventy-five even the strongest man is entitled to throw off some of his burdens. This is not the occasion, however, to review President Eliot's career as a whole; for he has, we trust, years of beneficent toil still ahead of him; our purpose is merely to touch on a few of the aspects of his administration at Harvard, and the causes which have made his the most notable career in the history of American education.

President Eliot would be the first to point out that he was fortunate in both the place and time of his labors. Harvard was the oldest college in the United States; it had the longest tradition of culture; it was at the center of the most highly educated and thoroughly civilized part of the union. Then, too, he assumed the presidency in 1869 , just at the beginning of that period of enormous agricultural and industrial expansion which followed the civil war. America was growing rich rapidly, and Harvard has shared this prosperity. Other colleges have also had their part in this general advancement: why has Harvard taken the lead? Why is it the foremost university in America to-day? There can be but one answer: Because President Eliot has displayed in extraordinary measure the qualities of a great leader. When the graduates of Harvard addressed him in a formal letter on his seventieth birthday, they said: "With prophetic insight you anticipated the movements of thought and life; your face was toward the coming day." This is perhaps the best definition of a leader-that he is a man who sees in the long march of events the coming of the inevitable, and sets himself to hasten it.

President Eliot foresaw the coming of the elective system. It had, indeed, already come, here and there, in a limited way. Many edu- 